\title{
Business Strategy Improvement for PT. XYZ to Achieve Competitive Advantage in Construction Industry
}

\author{
Takara Tantarto and Harimukti Wandebori
}

\begin{abstract}
PT. XYZ has been engaged in the construction services business for 48 years in Indonesia and this company pioneered its work as executor of building construction. At present, PT. XYZ is experiencing challenges due to the decrease in project targets per year set by the company so that it has an impact on revenue decline. Since the business problems occurred, the company has not developed a new strategy to increase the company's target.

This study aims to determine and improve company strategy based on the problems that occur and is expected to have an impact on increasing project targets. The methodology used in this study uses qualitative data obtained from interviews with the company's employees. Secondary data analysis was performed using the company's Annual Report and literature study.

The conceptual framework used begins with an analysis of the external environment using PESTEL analysis, Porter's 5 Forces, and competitor analysis. All analysis results are summarized in the SWOT analysis. The proposed strategy based on the results of the study with the TOWS Matrix, Authors provides an overview of the Strategy Map to achieve a competitive advantage.
\end{abstract}

\section{Index Terms - Construction Industry, Business Strategy.}

\section{INTRODUCTION AND RESEARCH OBJECTIVES}

Infrastructure is one of the mainstay programs of the government in catching up with other countries. President Joko Widodo reminded us that one of the keys to winning competition is through infrastructure development [1]. With the infrastructure development program launched by the government, construction companies, both government and private, are expected to continue aggressively in designing projects in the future. Because of that, is a chance for a construction company and new entrants to play aggressive in this industry. So, strategy management is needed to determine the right business strategy to compete. Strategy management allows a company to be more proactive than reactive in its efforts to shape the company's future itself, and it allows a company to start and influence activities so that it can control the company's own goals [2].

In this study, authors want to make PT. XYZ as the object of research. PT. XYZ is a publicly-traded company specializing in industrial services specializing in premium class building construction and focusing on building construction. The company has been established since 1970, with nearly 40 years of experience, the company handles many architectural, civil, mechanical, and environmental projects. PT. XYZ has built more than 800 buildings, which include commercial buildings, high- class apartments \& condominiums, offices, shopping centers, universities, hospitals, places of worship, TV stations, and others. Through this research, authors want to provide business strategy solutions that are considered more appropriate through several models of strategic management to overcome the problems that occur so that PT. XYZ can develop in achieving company goals and can face competition.

\section{A. Statement of the Problem}

Starting in 2018, the company's total revenues were decline. From the company's financial statements, over the past year, the company's revenue issuer dropped $5.11 \%$ to $\mathrm{Rp}$ 2.78 trillion.

While net profit fell $14.66 \%$ to $\mathrm{Rp} 208.66$ billion. In the third quarter of 2019, revenue fell again to Rp 2.03 billion. And also, the company never number reached the target projects per year.

\section{B. Research Objectives}

The objective of this research is to find out the strategic position of PT. XYZ in the construction industry, so that the company can survive facing competition and to find out the factors that influence the company's strategy and develop strategic management in order to make decisions appropriately according to company conditions.

\section{RESEARCH Methodology}

The research method used in this study was qualitative, data were compressed from the results of an interview with one of the company's employees. In addition, to support this research, literature studies include books, websites and journals are carried out. Supporting data obtained from the Annual Report.

\section{EXTERNAL ANALYSIS}

\section{A. Statement of the Problem}

An external environmental analysis needs to be done in this research to identify the opportunities and major threats faced by the company so that the company can formulate strategies to take advantage of these opportunities and minimize the impact of potential threats that arise. The company's external environment is all events outside the company that have the potential to influence the company [3]. The are several segments analyzed in this section: 


\section{- Political/Legal}

Since the start of the administration of President Joko Widodo (Jokowi), infrastructure development has become one of the main priorities, primarily aimed at encouraging economic growth and catching up with development that is compared to development in neighboring countries. This encourages the construction sector players to be vigorous in development so that the Indonesian construction market experiences fairly rapid growth [4]. Infrastructure was prioritized during the leadership of President Joko Widodo, the government's infrastructure development program is an opportunity for the construction service industry, including private companies to take part and play a role in national infrastructure development. An appeal from the President to make room for private construction companies, opening opportunities as well as challenges for the private construction industry to continue to improve capacity, skills, and quality, so they can compete. This also includes challenges in order to also be prepared to compete with foreign companies in the current free-market era.

The government together with the Dewan Perwakilan Rakyat (DPR) has officially issued Law No. 2 of 2017 concerning Construction Services. This law applies and becomes legal for all construction projects in Indonesia, both developed by the government and by the private sector. This UUJK factor requires construction companies to comply with applicable regulations. In general, this Law covers responsibilities and authorities, construction services business, security, health, and sustainability of construction, construction workforce, guidance, construction services information system, community participation, dispute resolution, administrative sanctions, and transitional provisions. In addition, companies that enter the construction industry must follow the Lembaga Pengembangan Jasa Konstruksi (LPJK) regulations, LPJK arrangements regarding Integrated Construction Services Business Registration are norms or regulations set by the National LPJK, national in nature that govern the requirements and registration process which includes classification, qualification, and business certification of integrated construction services.

\section{- Economic}

The construction sector is the third contributor to national growth [5]. This means that infrastructure development has driven the real economy which has an impact on the country's economic growth. Infrastructure is the key to economic growth, including equitable development, and therefore, a productive economy is also impossible to achieve if it is not supported by the availability of adequate infrastructure. This is also a positive impact on the construction industry because it means the company is in a stable economy and has growth potential.

\section{- Sociocultural}

In 2020, a global disaster in the form of a corona pandemic is hampering several construction industries because projects are stopped, especially in cities that are central to the pandemic. The 2020 calendar becomes something that can no longer be seen as a work reference because everything must be done through the home (work from home). Although fieldwork continues to run on projects that are not located in a city that is a pandemic center, activities are hampered considering that the PT. XYZ's headquarters located in Jakarta has to employ some employees to work at home.

Another thing that also becomes an obstacle and challenge at work today is the gap in work views and culture that occurs between generations because there is still a meeting between generations called the $\mathrm{X}$ generation and $\mathrm{Y}$ generation. The generation has negative traits such as narcissism and entitlement (arrogant) than its predecessor generation [6] Gaps in meetings between Generation $\mathrm{X}$ and $\mathrm{Y}$ often occur when Generation $\mathrm{X}$ considers it difficult to educate, print cadres, assume the performance of subordinates that are not in accordance with the standards even often regarded as a form of ignorance, and the difficulty of building the loyalty nature of their subordinates, while on the other hand, generation $\mathrm{Y}$ considers their superiors impractical, inefficient, lagging behind an understanding of technology, and salaries deemed inappropriate the current construction industry.

\section{- Technology}

The birth of new technologies in the construction sector makes work in the construction sector work quickly. For example, with the latest computers and software, project drawings and construction drawing designs, and building models can be calculated accurately using a CAD program, while the analytical calculations and strength analysis use SAP2000 or STAD III programs. Other software findings such as Revit, Archicad, and so on are very helpful in the process of understanding construction drawings. Along with technological developments and innovations, Building Information Modeling (BIM) emerged as a tool used to deal with these problems and facilitate the construction process itself. Building Information Modeling (BIM) is a 3D modelbased technology concept that contains all data and information about the actual object of the model. BIM is not an application or software (software). BIM is a digitalization process of a project or construction work, starting from creating a 3D model (building virtually) entering all building information data, to utilizing the model and information as a means of communication for all parties involved in the project. In utilizing the 4.0 industrial revolution, several Indonesian construction industries are actively developing integrated information systems that will become the big data supply chain of the construction services industry. This big data will later provide the data needed for all stages of construction, starting from planning, auctioning, construction, operation, and maintenance. From the big data, what will be done is the data on the entire population of the workforce, data on heavy equipment and construction materials that must be integrated into the Material Information System and Construction Equipment (SIMPK). This will make it easier during the tender process so that service providers can easily and quickly call all the data based on needs.

\section{- Physical}

The construction industry plays an indispensable role in playing an indispensable role in providing physical infrastructure to meet the needs of the community [7]. Some of the middle and upper construction industries have implemented sustainable development and pay attention to several aspects and environmental impacts. The application of green construction has become a reference for companies 
when doing every job. Every year, in the annual competition, all company projects in the best green construction category also become one of the competed numbers, in addition to other numbers: the best innovation, the best project manager, the best effective material consumption, and so on. This competition has become the strength of the company to continue to compete for good. The challenge going forward is also to make the evaluation category in the direction of showing more technological capabilities in order to support the concept of sustainable development, especially in the case of green construction.

\section{B. Statement of the Problem}

Competitor analysis conducted in this study was completed on objective; current goals, targets, and attitudes towards risk, assumptions; do we consider the future to be volatile? do we operate the status quo? and what assumptions do our competitors have about the industry, strategy; current strategies and strategies that support change, company capabilities; strengths and weaknesses as well as how the company fought against competitors, the final response; what will the company do in the future and where we have an advantage over our competitors? This needs to be analyzed to discuss their positions and strategies. Every aspect of competitor analysis will be a reference that supports what needs to be improved in order to be able to integrate it with the needs of the competition.

\section{Statement of the Problem}

The Industry Environment was analyzed using Porter's Five Forces Method. This method observes 5 things, namely:

1) Bargaining Power of Buyers; 2) Bargaining Power of Suppliers; 3) Threat of New Entrants: 4) Threat of Substitute Product or Service; and 5) Intensity of Rivalry Among Industry.

\section{- Bargaining Power of Buyers/ Buyers'Power}

The bargaining power of buyers in this industry is categorized medium. The ease of information obtained by the buyer is a benefit for the buyer himself. Information about the buyer of the company can be known, especially information about how to operate and how to calculate the tariffs, it has also been stated in the Construction Project Bidding Document. However, this information can be obtained if the buyer has communicated directly with the parties from the company. Information about construction services about prices and costs can be negotiated according to the agreement contained in the employment contract. This causes the buyer does not have the power to get a lower price than the price offered by the company.

- Bargaining Power of Suppliers/ Suppliers' Power Bargaining power of suppliers for the construction industry is categorized as high. Suppliers have an influence in terms of preparing the materials needed with the best quality at competitive prices. The way companies increase the number of customers so they can make a profit is by producing something of good quality at competitive prices.

\section{- Threat of New Entrants}

The threat of new entrants in the construction is categorized medium. The construction industry is an industry that has a strong relationship between the company and the customer. The reputation of the construction company is very important because it shows the customer's confidence in the work of the company. New customers in the industry will see the reputation of the construction service company and recommendations from other customers. For newcomers, to build customer loyalty, will require a pretty heavy effort, they must build a reputation through a lot of experience that must be done with a long enough time, and not necessarily successful anyway. Repeated purchases from customers have proven that customers choose not to change companies because they already have more trust in old players. The construction industry will use a large enough capital in the establishment of businesses, the average authorized capital of the middle to upper-class construction industry is worth Rp. 500 billion or even more for large scale projects. Newcomers can get credit from the bank easily if they have a work order and good work experience. Capital requirements for new entrants are said to be large because they need to buy the required assets.

\section{- Threat of Substitute Product or Services}

The threat of substitute product or services is categorized as low. Substitution products from corporate building products can also be said as substitution services. Substitution services from development services are building foreman services. Foreman building services are substitution services which are individual services of experts with the assistance of freelancers to do construction work. At present, the number of foreman services that have sprung up, moreover information on available foreman services is very easy to know. A foreman is a person who is able to coordinate work. In this digitalization era, many foreman services that promote their businesses online will be easy for people to access. However, the availability of replacement services for uppermiddle-class contractors will be difficult because the industry is always working on large projects, while foreman services are usually only able to work on small projects with a maximum of 4 floors. Plus, the clarity and name of the foreman's services are of doubtful quality in carrying out large projects. This will be an advantage for old players in facing the threat of substitute products.

\section{- Intensity of Rivalry Among Industry}

The threat of new entrants in the construction is categorized high. The growth of the construction industry will add competition in the struggle for market share. Opportunities for Indonesia's construction development are reflected in growth targets Indonesia's development opportunities include reflected in the Indonesian state which needs adequate infrastructure support to achieve economic growth targets. Indonesian construction since 2017 is designed to boost national economic growth. Indonesia's current potential population of around 269 million and the value of building construction in 2020 which grew from the previous year to around 168 trillion encourages the growth of the construction industry in Indonesia. The value of building construction in 2020 is the highest point in the last five years, 2016-2020 [8]. In fact, from the growth side, it became the latest record considering that in the span of time the building construction was quite volatile and tended to weaken. This will encourage construction business developers to start stretching in the world of construction services considering that after a few years there has been a slowdown. The growth of the construction industry will continue to increase with 
new projects and rapid development in the regions. Based on existing data, increased industrial growth in 2020 and the presence of new development projects will trigger intense competition that will be experienced by some construction industries.

After describing each category in this Porter 5 Forces analysis, it can be concluded that competition in the medium to high fashion industry. From this analysis, the threats and opportunities that can be used as a corporate strategy to compete in the construction industry in the future are obtained.

\section{TOWS MATRIX}

TOWS Matrix will be used to bring together key internal and external factors in making corporate strategy. The TOWS matrix will match environmental threats and opportunities with the company's weaknesses and strengths [9]. These factors will systematically identify the relationships that underlie the company's strategy. The core of TOWS Matrix is the formulation of a combined strategy of internal and external components to produce four kinds of combination strategies, the four types of combination strategies are:

- $S$-O (Strength-Opportunity) Strategy

This strategy combines the strengths and weaknesses components of the company, so that strategies are generated to seize opportunities that exist with the strengths of the company.

\section{- W-O (Weakness-Opportunity) Strategy}

This strategy combines the components of weaknesses and opportunities owned by the company to produce a strategy to minimize the weaknesses that are owned by utilizing existing opportunities.

\section{- $\quad$ S-T (Strength-Threat) Strategy}

This strategy combines the strength and threat components of the company to produce a strategy to minimize existing threats with the strengths that they have.

\section{- W-T (Weakness-Threat) Strategy}

This strategy combines the weakness and threat components of the company so that a strategy will be produced to minimize the weaknesses that are owned while avoiding business threats.

\section{CONCLUSION}

The strategy for conclusions for PT. XYZ problems are: The company has decreased revenue due to the number of projects decreasing from year to year, because PT. XYZ cannot highlight competitive advantage in the tender process so that a proposed new strategy is changed from Differentiation Strategy to Integrated Differentiation \& Cost Leadership Strategy. PT. XYZ has adequate resources, so as to maximize the productivity of resources and provide a competitive advantage, it is necessary to propose functional strategies that include Marketing, Operations, IT, and Human Capital Strategy. PT. XYZ needs to revise the organizational structure to be in line with alternative strategies to build a competitive advantage. In this study, authors propose a map strategy that can be used as an implementation plan based on the business solution described in the previous chapter to develop integrated differentiation and cost leadership strategies that are divided into business levels. The figure below is the level of business that authors propose in carrying out integrated differentiation and cost leadership strategies.

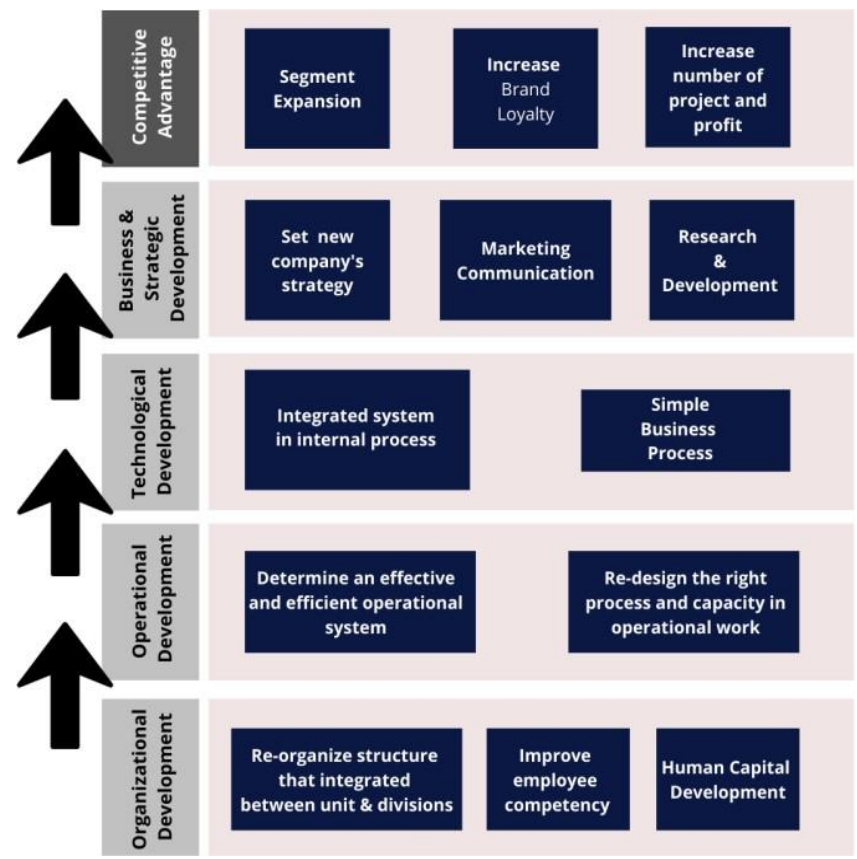

Fig. 1. Map Strategy.

After determining the strategy map, the authors make a plan for implementing the strategy and designing resources that support the implementation of the strategy. Thick below is a draft implementation plan prepared by authors:

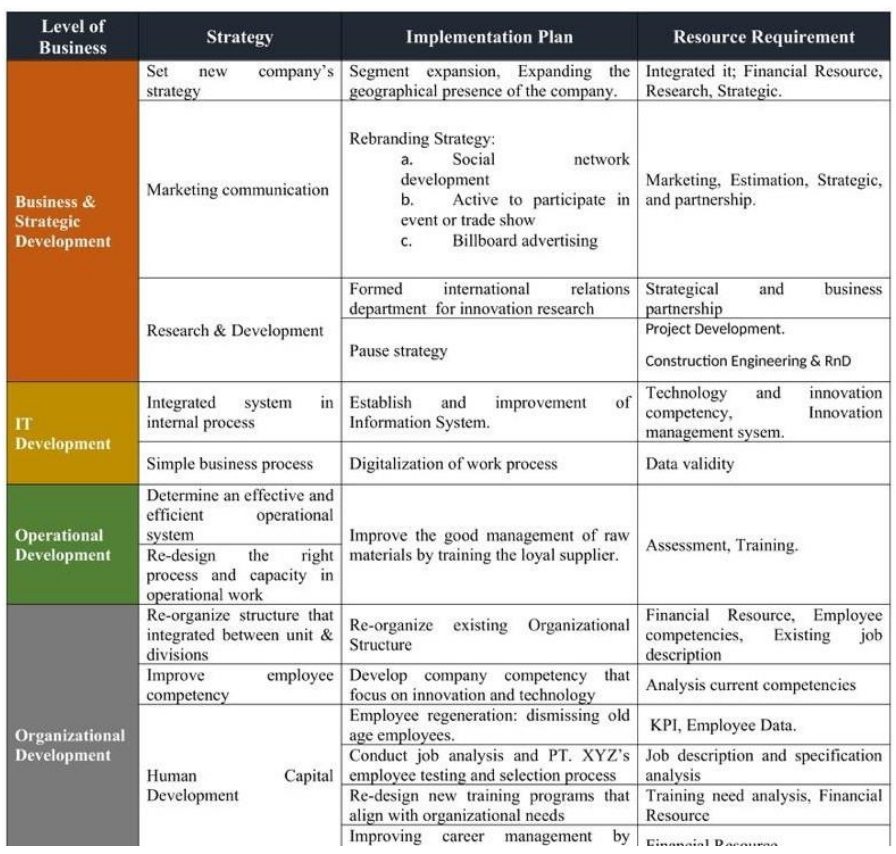

Fig. 2. Implementation Plan. 
Table 1: PT. XYZ TOWS Matrix

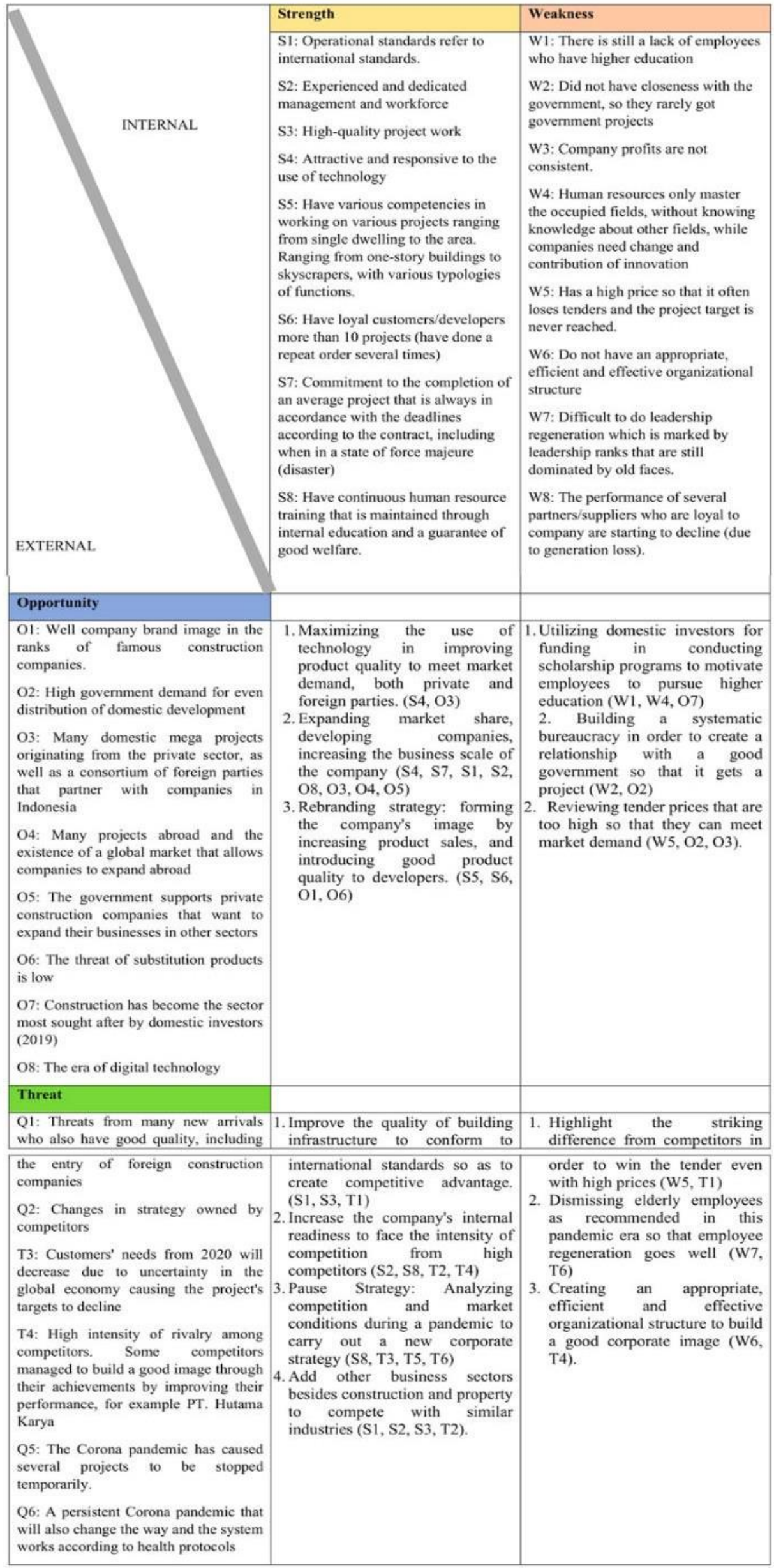




\section{REFERENCES}

[1] Humas. (2017). Presiden Jokowi: Pembangunan Infrastruktur Untuk Kejar Ketertinggalan Dari Negara Lain. https://setkab.go.id/presidenjokowi-pembangunan-infrastruktur-untuk- kejar-ketertinggalan-darinegara-lain/.

[2] Taufiqurokhman. (2016). Manajemen Strategik. Jakarta: Fakultas Ilmu Sosial dan Ilmu Politik Universitas Prof. Dr. Moestopo Beragama.

[3] Williams, C. (2001). Manajemen (terj). Jakarta: Salemba Empat, 51.

[4] Detik Finance. (2017). https://finance.detik.com/berita-ekonomibisnis/d-3586268/jokowi-gencar-bangun-infrastruktur-pasarkonstruksi-booming (Quoted on January 18, 2020).

[5] Badan Pusat Statistik, 2019.

[6] DeVaney, S. A. (2015). Understanding the millennial generation. Journal of Financial Service Professionals, 69(6).

[7] Muhwezi, L., Kiberu, F., Kyakula, M., \& Batambuze, A. O. (2012). An assessment of the impact of construction activities on the environment in Uganda: A case study of Iganga municipality. Journal of construction Engineering and Project Management, 2(4), 20-24.

[8] Rusyanto, E. 2019. 2020, Konstruksi Bangunan Tumbuh 13,82\%. https://investor.id/business/2020-konstruksi- bangunan-tumbuh-1382.

[9] Weihrich, H. (1982). The TOWS matrix-A tool for situational analysis. Long range planning, 15(2), 54-66.

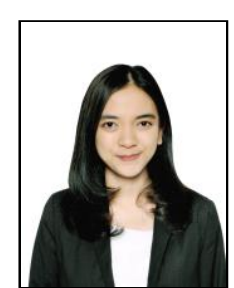

Takara Tantarto, S. I. Kom was graduated from Brawijaya University in 2018 majoring Communication Studies. She continued her postgraduate education in Business Administration at Bandung Institute of Technology, Indonesia. She focused on the concentration of General Management and Human Capital. Research topics that have been carried out are related to Consumer Preference, Diffusion Innovation, Technology Adoption, and Business Strategy.

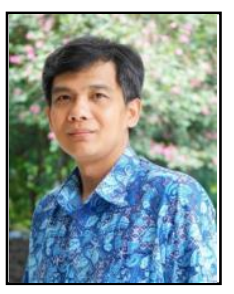

Harimukti Wandebori, ST MBA, Ph. D was completed his doctoral program at the University of Twente, the Netherlands in the International Strategic Alliance, and graduated in 2010. Previously, Harimukti took an MBA in Corporate Strategy and Economic Policy at the Maastricht School of Management and graduated in 2001. Harimukti was much involved in research with the Strategic Alliance, Strategic Management, and Marketing Management area. At present, he works as a lecturer with an Interest Group in Business Strategy and Marketing. 